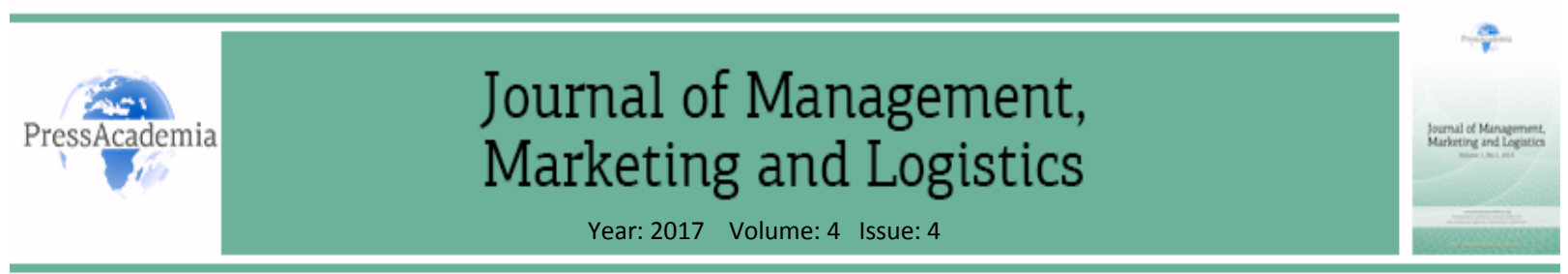

\title{
UNDERSTANDING NOSTALGIC CONSUMERS IN A RETAIL ENVIRONMENT: A REVIEW
}

\author{
DOI: 10.17261/Pressacademia.2017.721 \\ JMML- V.4-ISS.4-2017(1)-p.327-334
}

\section{Katija Vojvodic}

University of Dubrovnik, Department of Economics and Business Economics, Lapadska obala 7, Dubrovnik, Croatia. atija.vojvodic@unidu.hr

To cite this document

Vojvodic, K. (2017). Understanding nostalgic consumers in a retail environment: a review. Journal of Management, Marketing and Logistics (JMML), V.4, Iss.4, p.327-334.

Permanent link to this document: $\underline{\text { http://doi.org/10.17261/Pressacademia.2017.721 }}$

Copyright: Published by PressAcademia and limited licenced re-use rights only.

\begin{abstract}
Purpose - The role of nostalgia in the context of retailing is an intriguing area of research. However, previous research has mainly focused on consumer nostalgia in the context of product advertising. This paper aims to identify the main features of consumers' retail nostalgia and to determine a framework for classification and analysis.

Methodology - The paper presents the results of an extensive review of the recent literature on the role of nostalgia in the retail context and consumer-related behaviour.

Findings - Useful insigths for both retailers and marketers are provided in order to better understand the concept of consumer nostalgia and to enhance the overall retail experience of nostalgic consumers. Consequently, it helps target and capture the segment of nostalgic consumers more effectively.

Conclusion - The paper summarizes the relevant retail-related research on consumer nostalgia and provides a framework for an improved understanding of nostalgic consumers in the retailing environment.
\end{abstract}

Keywords: Consumer nostalgia, nostalgic brands, nostalgic consumers, retail environment.

JEL Codes: L81, D11, M31

\section{INTRODUCTION}

In the context of retail store, creating an appealing store atmosphere is an extremely challenging task. Nowadays, retail environments are designed intentionally to evoke memories of the past (Babin and Borges, 2009). For this reason, many firms use nostalgia to stimulate positive emotions and awaken consumers' childhood memories (Kardes, Cronley and Cline, 2011). Moreover, nostalgia evoked by brands is at the forefront of contemporary marketing theory and practice (Bartier and Friedman, 2013). As regards the retail space, it has been suggested that the essential interplay between product, ritual and aesthetics creates positive moods of belonging and sharing and may increase satisfaction (Hamilton and Wagner, 2014). Furthermore, the feelings that accompany nostalgia create approach behaviours that may lead to shopping value, but the feelings themselves also create value directly in the form of hedonic shopping value (Babin and Borges, 2009).

In addition to brand's physical attributes, brands that are associated with life event experiences can be stored in consumer memory (Ratnayake and Andrews, 2016). Consequently, consumers may feel personal or emotional attachment to the brands used during childhood. As stressed by Elliott and Percy (2007), brands can acquire deep meaning for consumers by their involvement in the socialization process of growing up, and from then on brands can evoke profound feelings of nostalgia. Additionally, Levy, Weitz and Grewal (2014) pointed out that the value of the brand is largely based on the associations that customers make with the brand name.

Over the past two decades, there has been growing interest in the issue of nostalgia, mainly in the context of marketing, and specifically product advertising. There is a considerable amount of literature on nostalgic advertising and consumers' responses to nostalgia-themed advertisements (e.g., Pascal, Sprott, and Muehling, 2002; Muehling and Sprott, 2004; Bambauer-Sachse and Gierl, 2009; Kusumi, Matsuda and Sugimori, 2010; Muehling and Pascal, 2011; Marchegiani and Phau, 2012; Muehling and Pascal, 2012; Merchant et al., 2013; Chou, 2014; Muehling, Sprott and Sultan, 2014; Zhao, Muehling \& Kareklas, 2014; Chang and Feng, 2016; Ju et al., 2016a; Ju et al., 2016b; Srivastava, Maheswarappa and Sivakumaran, 2017). In light of this, nostalgic advertisements have been proved to evoke more positive emotions and more intensive mental images than non-nostalgic advertisements, which in turn affect consumers' attitudes toward the product 
and their purchase intentions (Bambauer-Sachse and Gierl, 2009). In addition, the role of nostalgic feelings in online brand communities was also explored (Koetz and Tankersley, 2016).

However, contrary to the above-mentioned studies, not much is known about the role of nostalgia in the retail context. To advance understanding of consumers' nostalgia in the retail environment, the paper presents the results of an extensive review of the recent literature on consumers' nostalgic behaviour. The purpose of the paper is to identify the main features of consumers' retail nostalgia and to determine a framework for classification and analysis. To this end, the paper is structured as follows. Following the introduction, the concept of nostalgia is discussed in the second section. The third section examines key components of nostalgic brands, whereas the features of nostalgic consumers are analysed in the fourth section. Finally, some conclusions are drawn in the last section.

\section{THE CONCEPT OF NOSTALGIA}

In their paper on the phenomenon of nostalgia in consumer behaviour, Holbrook and Schindler (1991) defined nostalgia "as a preference (general liking, positive attitude, or favourable affect) toward objects (people, places, or things) that were more common (popular, fashionable, or widely circulated) when one was younger (in early adulthood, in adolescence, in childhood, or even before birth)". When examining the emotional components of nostalgia, Holaka and Havlenab (1998) placed a great emphasis on the complexity of the emotions elicited in nostalgic experience. As a result, positive emotions such as warmth, joy, affection, and gratitude are linked with sadness and desire to produce a mixed affective response.

On the one hand, Sedikides and Wildschut (2016) stressed that nostalgia endured a negative reputation as an unhealthy preoccupation with one's past. On the other hand, they highlighted that nostalgia strengthened approach orientation, raised optimism, evoked inspiration, boosted creativity, and kindled prosociality. Similarly, Hetsroni (2012) associated the nostalgic mood with warmth, spontaneity, a change of time perception, and the maintenance of some mental distance from everyday life. Furthermore, Huang, Huang and Wyer (2016) argued that nostalgia could counteract loneliness and promote prosocial behaviour.

It can be observed that two types of nostalgia are mainly reported in the literature - historical and personal (Stern, 1992). In examining the two prevalent types of nostalgia, Muehling (2013) reported that responses of a personally nostalgic nature tended to predominate and were more influential in shaping brand attitudes. In their research, Sultan, Muehling and Sprott (2010) argued that nostalgia was intensely personal and that it worked the best for current consumers who had personal attachments with the brand used during childhood. Likewise, LaTour, LaTour and Zinkhan (2010) found that memories from early childhood were more predictive for understanding current brand attitudes than memories coming from adolescence. However, although personal nostalgia has been found to be distinctly different from historical or 'unified' nostalgia, Marchegiani and Phau (2009) stressed a lack of empirical research conducted. Furthermore, in her paper on nostalgia in the context of branding entertainment media, Natterer (2015) found that personal and historical nostalgia effect on attitude, buying intention, affective response, and mood after consumption were highly significant.

Further, Boym (2001) looked at restorative and reflective nostalgia. In that context, it has been emphasized that restorative nostalgia evokes national past and future, whereas reflective nostalgia is connected with individual and cultural memory. In their analysis, Kessous and Roux (2008) focused on the most important features of nostalgia, i.e. "long-standing nostalgia" (continuity) and "first-time nostalgia" (discontinuity). As a result, a typology of four nostalgic moments linked to specific brands and objects was determined, including everyday past, uniqueness, tradition and transition. In addition to previously mentioned categorization, Zhao et al. (2014) investigated two types of consumer nostalgias - individualistic nostalgia and collectivistic nostalgia. According to Cook and Ryan (2015), nostalgia is a part of a globalized and shared consumer culture that emphasizes collective emotion.

Overall, nostalgia is considered to influence attitudes and behaviours (Routledge, 2015). As proposed by Shin and Parker (2017), three distinct types of consumer nostalgic memories related to retailing experiences can be identified, i.e., general autobiographical memories, specific autobiographical memories, and retailer feature-based memories. Following this, six key elements that comprise retailer-related consumer nostalgic memories were highlighted. More specifically, elements that shape retailer nostalgic memory include individuals, merchandises, store servicescape, retailer knowledge, promotional materials, and usage/shopping occasions (Shin and Parker, 2017).

Although nostalgia has been identified as a universal and persistent phenomenon encountered globally (Jain, Chandani and Ganesh, 2016), Zhao et al. (2014) state that nostalgia appeals are unlikely to be universally effective. Likewise, as observed by Marchegiani and Phau (2010), treatment of nostalgia as a "unified" concept may be inaccurate in predicting true consumer responses. Based on these findings, it can be observed that more research is still needed to better identify the concept of consumer nostalgia, in particular with regard to nostalgic cues in the retailing environment. 


\section{DETERMINING KEY COMPONENTS OF NOSTALGIC BRANDS}

In the literature there seems to be no clear definition of nostalgic brands. In that context, Bartier (2012) highlighted that researches have failed to provide an agreement on the definition and the composition of nostalgic brands. According to Levy, Weitz and Grewal (2014), "brand associations are anything linked to or connected with the brand name in a consumer's memory" (p. 435). In the sense of nostalgic attachment, it is argued that the brand should evoke pleasant memories because the consumer used it in the past (de Chernatony, McDonald and Wallace, 2011). In addition, Lemmetti and Tuominen (2017) pointed out that nostalgic brand associations could be drawn from either consumer's personal or communal associations. Notwithstanding, as observed by O'Shaughnessy (2015), what is nostalgic for one audience is not necessarily nostalgic for another.

It is important to emphasize that nostalgic brands are sometimes mistaken for retro brands. Although retro brands are perceived as nostalgic (Hemetsberger, Kittinger-Rosanelli \& Mueller, 2010), a distinction should be made between retro brands and pure nostalgic brands. According to Kral (2012), "retro branding refers to the revival or re-launch of a product or service brand from a prior historical period, which is usually, but not always, updated to contemporary standards of performance, functioning or taste" (p. 115). In other words, retro brands include the attribute of updating. In light of this, Cattaneo and Guerini (2012) found that consumers appeared to prefer updated brands with nostalgic associations to pure retro brands. The study by Orth and Gal (2012) indicated that nostalgic rather than non-nostalgic brands boosted consumers' moods. Likewise, it is argued that nostalgic brands have been found to boost consumers' moods and drive behavioural intention (Percy and Elliott, 2016).

Life satisfaction was identified as an antecedent variable for evoked nostalgia (Ju et al., 2017). As outlined by Bartier (2012), the level of nostalgia evoked by a brand may vary from one consumer to another as well as from one nostalgic brand to another. In addition, three characteristics that form the power of nostalgia toward the brand consist of perceived oldness of brand, recall of consumers' lived or learned past memories and elicitation of feelings (Bartier, 2012). Consumers' preference for nostalgic brands can be based on recapturing past feelings or memories. In that context, Shields and Johnson (2016a) defined childhood brand nostalgia as a positively valenced emotional attachment to a brand.

In general, brand communication is concerned with conveying the voice of the brand (Wang, 2013). In light of this, nostalgic attachment is a valuable starting point for building long-lasting brand relationships (Lemmetti and Tuominen, 2017). On the other hand, Demirbag-Kaplan et al. (2015) affirmed that nostalgia might play an important role in maintaining an otherwise failed brand relationship. Despite different scales developed to measure the propensity to be nostalgic, little attention has been paid to measure consumers' perceptions of the nostalgia aroused by brands (Bartier and Friedman, 2013). In that sense, Zhao et al. (2014) emphasized that evoked nostalgia about a brand was positively related to attitude toward the brand.

Likewise, Kessous, Roux and Chandon (2015) examined consumer-brand relationships change in the context of brands perceived as nostalgic and those perceived as non-nostalgic. The results showed that a brand's nostalgic status had a positive effect on attachment, self-brand connections, and storytelling, whereas the nostalgic status of a brand had positive effects in terms of intention to purchase the brand as a gift and collect brand-derived products. Similarly, the relationships and attitudes of consumers towards nostalgic brands were found to be systematically stronger than for non-nostalgic brands (Kessous and Roux, 2010). Further, the study by Orth and Gal (2015) provided evidence that less authentic nostalgic brands evoked higher levels of mixed emotions whereas authentic brands evoked lower levels of mixed emotions. In her recent study, Kessous (2015) examined the impact of culture on the consumer relationship with brands considered as nostalgic. The findings revealed that culture involved sweeter rather than bitter nostalgic brand relationships.

\section{UNCOVERING NOSTALGIC CONSUMERS IN THE RETAIL ENVIRONMENT}

According to Hoyer, MacInnis and Pieters (2013), "consumer memory is the persistence of learning over time, via the storage and retrieval of information, which can occur consciously and unconsciously" (p. 102). Previous research on consumer nostalgia has concluded that nostalgic feelings primarily have a positive effect on consumers, boosting positive feelings and affective responses (Shields and Johnson, 2016b). In their study, Orth and Bourrain (2004) examined consumer response to scent-evoked nostalgic memories. Nostalgic memories were found to positively influence consumer affect with downstream effects onto risk taking, variety seeking, and curiosity-motivated behaviour. On the other hand, it is often emphasized that nostalgia is one way in which memory clearly links to shopping emotion, experience, and value (Babin and Borges, 2009).

When examining the use of nostalgia in brand communication, Kessous and Roux (2013) identified four profiles of nostalgic consumers, i.e., "kidult", traditional, transitional and transgenerational. In addition, highly nostalgic consumers have been found to be more sensitive to nostalgic triggers (Kusumi, Matsuda and Sugimori, 2010). Further, Orth and Gal (2014) showed that two forms of authenticity, indexicality (a genuine historic link to the past), and iconicity (a symbolic link) 
influenced behavioural intention through the diverging emotion elicited by nostalgic memories and perceived persuasive intent.

In general, consumers who belong to the same age group face crucial life stages approximately at the same time. As a result, the values and symbolism used to appeal to them can evoke powerful feelings of nostalgia (Solomon et al., 2006). For example, the phenomenon of population aging is worth mentioning. It can be argued that aging has been identified as a critical element affecting changes in consumers' retail buying behaviour. As observed by Kusumi, Matsuda and Sugimori (2010), aging facilitates a predisposition toward nostalgia. More recent evidence (Kazlauske and Gineikiene, 2017) suggests that the bigger the discrepancy between one's chronological and cognitive age, the more nostalgic products one buys.

Another important issue refers to the effects of consumers' insecurity on their preferences for nostalgic products. In light of this, Zhou et al. (2013) noticed that existential insecurity and social insecurity enhanced consumers' preference for nostalgic products. In addition, the conditions under which consumers experience an increased preference for nostalgic products are worth examining. With this in mind, Loveland, Smeesters and Mandel (2010) pointed out that the consumption of nostalgic products successfully satiated the need to belong. Their findings revealed that consumers for whom the need to belong was an active goal experienced a significantly stronger preference for nostalgic products. Furthermore, the relationship between nostalgia and consumer patience is diminished when people perceive a nostalgic experience to be repeatable or when they intensify their memory of the experience (Huang, Huang and Wyer, 2016).

As regards packaging design, evoking nostalgic feelings through design can generate positive emotions to enhance consumer satisfaction effectively (Chen, 2014). Additionally, consumers' recalled experiences involving packaging were analysed by Ryynänen, Joutsela and Heinonen (2016). In that context, the dimensions of nostalgic experience included the involvement of key persons, the places and physical spaces in which the experience happened, and actions or practices involving packaging during an experience. Further, Kessous, Magnoni and Valette-Florence (2014) investigated the role of nostalgia in the consumer-brand relationships in the luxury sector. The results of their study indicated that the nostalgic luxury car brands lead to stronger consumer-brand relationships. Moreover, brand nostalgia had a direct positive effect on brand attachment and separation distress. Additionally, Chen, Yeh and Huan (2014) analysed consumption intentions of customers of nostalgic-themed restaurants. In examining links between nostalgia and food consumption, Vignolles and Pichon (2014) suggested six themes of food nostalgia, i.e., childhood, yearning, substitute, homesickness, special occasions and rediscovery. However, the issue of nostalgic consumption in the context of services remains largely unknown (SegerGuttmann and Vilnai-Yavetz, 2015).

Further, Rindfleisch, Freeman and Burroughs (2000) addressed the roles of nostalgia and materialism in shaping consumers' preferences for everyday products and services. The results from their studies suggested that nostalgia was negatively related to materialism. Furthermore, materialism and nostalgia were found to be somewhat oppositional. For this reason, marketers should pay a great deal of attention when combining these appeals. Likewise, in their study, Lasaleta, Sedikides and Vohs (2014) found that feeling nostalgic decreased people's desire for money. Similarly, research on the relationship between nostalgia, innovativeness and consumer purchasing decisions revealed that innovativeness and nostalgia might act in opposite directions (Barauskaite and Gineikiene, 2017).

\section{CONCLUSION}

Based on a comprehensive review of literature, the paper summarizes the relevant retail-related research on consumer nostalgia. Moreover, it provides a framework for an improved understanding of nostalgic consumers and their retail-related behaviour. Further, the paper contributes to the existing body of literature on consumer nostalgia and nostalgic consumers in the retailing environment by synthesizing different research on the issue. The paper also provides useful insights for retailers and marketers approaching nostalgic consumers and developing products and services to meet their requirements.

As was pointed out previously, the concept of consumer nostalgia in the retail context remains an understudied topic. Future studies should concentrate on uncovering the links between retailer-related consumer nostalgic memories and the overall retailing experience. Nevertheless, due to the complexity of consumers' feelings, thoughts and memories, an interdisciplinary approach should be considered to cover the issue in more depth. Consequently, in the context of retail environment, future work should deal with nostalgic triggers affecting consumers' shopping behaviour, as well as nostalgic memories related to retailing experiences.

The findings presented in the paper may be useful to all subjects involved in creating an appropriate retailing environment for nostalgic consumers. Such an environment can affect consumers' relationship with the retailer, and positively influence their shopping behaviour. Moreover, retailers' effort to build consumer nostalgia might result in improving brand loyalty, and developing consumers' long-term loyalty toward a retailer. For this reason, understanding nostalgic consumers is crucial for both retailers and marketers in order to target this market segment more effectively. 
In conclusion, the paper provides the synthesis of the most current theoretical and practical knowledge available. As such, it can serve as a basis for conducting future empirical research in the field. Taking into consideration that no empirical analysis has been undertaken, the paper lacks a contribution to the field from an empirical point of view. To this end, additional research is needed to provide empirical support to broaden current knowledge of retail nostalgia and to deepen understanding of the topic.

\section{REFERENCES}

Babin, B.J. \& Borges, A. (2009), Oh yeah, I remember that store! Memory, experience, and value. In: Lindgreen, A., Vanhamme, J. \& Beverland, M.B. (Eds), Memorable Customer Experiences: A Research Anthology, Burlington: Gower Publishing, pp. $161-176$.

Bambauer-Sachse, S. \& Gierl, H. 2009, Effects of Nostalgic Advertising Through Emotions and the Intensity of the Evoked Mental Images. In: McGill, A. \& Shavitt, S. (Eds), NA - Advances in Consumer Research, vol. 36, Duluth, MN: Association for Consumer Research, pp. $391-398$.

Barauskaite, D. \& Gineikiene, J. 2017, “Nostalgia may not work for everyone: The case of innovative consumers", Organizations and Markets in Emerging Economies, vol. 8, no. 1, pp. 33-43.

Bartier, A.-L. 2012, "Things were better before": what is the power of nostalgia toward the brand? 11th International Marketing Trends Conference, Venice, Italy, 19-21 January 2012

Bartier, A.-L. \& Friedman, M. 2013, Nostalgia Evoked by Brands: A First Step Towards Scale Development and Validation, Ideas in Marketing: Finding the New and Polishing the Old, Kubacki, K. (Ed), Proceedings of the 2013 Academy of Marketing Science (AMS) Annual Conference, pp. 392-392.

Boym, S. 2001, The Future of Nostalgia, New York: Basic Books.

Cattaneo, E. \& Guerini, C. 2012, "Assessing the revival potential of brands from the past: How relevant is nostalgia in retro branding strategies?" Journal of Brand Management, vol. 19, no. 8, pp. 680-687.

Chang, C.T. \& Feng, C.C. 2016, "Bygone eras vs. the good Ol' days: how consumption context and self-construal influence nostalgic appeal selection", International Journal of Advertising, vol. 35, no. 3, pp. 589-615

Chen, J.C.-C. 2014, "The impact of nostalgic emotions on consumer satisfaction with packaging design", Journal of Business and Retail Management Research, vol. 8, no. 2, pp. 71-79.

Chen, H.B., Yeh, S.S. \& Huan, T.C. 2014, "Nostalgic emotion, experiential value, brand image, and consumption intentions of customers of nostalgic-themed restaurants", Journal of Business Research, vol. 67, no. 3, pp. 354-360.

Chou, H.-Y. 2014, “Old Songs Never Die: Advertising Effects of Evoking Nostalgia With Popular Songs”, Journal of Current Issues \& Research in Advertising, vol. 35, no. 1, pp. 29-49.

Cook, D.T. \& Ryan, J.M. (Eds) 2015, The Wiley Blackwell Encyclopedia of Consumption and Consumer Studies, Chichester: Wiley-Blackwell.

de Chernatony, L., McDonald, M. \& Wallace, E. 2011, Creating Powerful Brands, Oxford: Butterworth-Heinemann.

Demirbag-Kaplan, M., Yildirim, C., Gulden, S. \& Aktan, D. 2015, "I love to hate you: Loyalty for disliked brands and the role of nostalgia", Journal of Brand Management, vol. 22, no. 2, pp. 136-153.

Elliott, R. \& Percy, L. 2007, Strategic Brand Management, Oxford: Oxford University Press.

Hamilton, K. \& Wagner, B.A. 2014, “Commercialised nostalgia: Staging consumer experiences in small businesses", European Journal of Marketing, vol. 48, no. 5/6, pp. 813-832.

Hemetsberger, A., Kittinger-Rosanelli, C. \& Mueller, B. 2010, "Grandma's fridge is cool - The meaning of retro brands for young consumers", Advances in Consumer Research, vol. 38, pp. 242-248.

Hetsroni, A. 2012, Advertising and Reality: A Global Study of Representation and Content, London: Continuum International Publishing Group.

Holaka, S.L. \& Havlenab, W.J. 1998, "Feelings, Fantasies, and Memories: An Examination of the Emotional Components of Nostalgia", Journal of Business Research, vol. 42, no. 3, pp. 217-226.

Holbrook, M.B. \& Schindler, R.M. 1991, Echoes of the Dear Departed Past: Some Work in Progress on Nostalgia. In: Holman, R.H. \& Solomon, M.R. (Eds), NA - Advances in Consumer Research, vol. 18, Provo, UT: Association for Consumer Research, pp. 330-333.

Hoyer, W.D., MacInnis, D.J. \& Pieters, R. 2013, Consumer Behavior, $6^{\text {th }}$ edition, Mason: South-Western Cengage Learning.

Huang, X., Huang, Z. \& Wyer, R.S., Jr. 2016, "Slowing down in the good old days: The effect of nostalgia on consumer patience", Journal of Consumer Research, vol. 43, no. 3, pp. 372-387.

Jain, V., Chandani, K. \& Ganesh, B.E. 2016, "Developing a sequential framework for nostalgia deployment: the Indian context", Middle East Journal of Management, vol. 3, no. 3, pp. 244-265. 
Ju, I., Choi, Y., Morris, J., Liao, H.-W. \& Bluck, S. 2016a, “Creating Nostalgic Advertising Based on the Reminiscence Bump: Diachronic Relevance and Purchase Intent", Applied Cognitive Psychology, vol. 30, no. 3, pp. 465-471.

Ju, I., Kim, J., Chang, M.J. \& Bluck, S. 2016b, "Nostalgic marketing, perceived self-continuity, and consumer decisions", Management Decision, vol. 54, no. 8, pp. 2063-2083.

Ju, I., Jun, J.W., Dodoo, N.A. \& Morris, J. 2017, "The influence of life satisfaction on nostalgic advertising and attitude toward a brand", Journal of Marketing Communications, vol. 23, no. 4, pp. 413-427.

Kardes, F.R., Cronley, M.L. \& Cline, T.W. 2011, Consumer Behaviour, Mason: South-Western Cengage Learning.

Kazlauske, D. \& Gineikiene, J. 2017, "Do you feel younger enough to choose nostalgic products? Exploring the role of age identity in nostalgic purchasing behaviour", Baltic Journal of Management, vol. 12, no. 3, pp. 292-306.

Kessous, A. \& Roux, E. 2008, "A semiotic analysis of nostalgia as a connection to the past", Qualitative Market Research: An International Journal, vol. 11, no. 2, pp. 192-212.

Kessous, A. \& Roux, E. 2010, "Brands Considered as "Nostalgic": Consequences on Attitudes and Consumer-brand Relationships", Recherche et Applications en Marketing, vol. 25, no. 3, pp. 29-55.

Kessous, A. \& Roux, E. 2013, "Nostalgia, autobiographical memories and brand communication: a semiotic analysis", Marketing ZFP, vol. 35, no. 1 , pp. 50-57.

Kessous, A., Magnoni, A. \& Valette-Florence, P. 2014, Brand Nostalgia and Consumers' Relationships to Luxury Brands: A Continuous and Categorical Moderated Mediation Approach, Abdi, H., Vinzi, V.E., Russolillo, G. Saporta, G. \& Trinchera, L. (Eds), International Conference on Partial Least Squares and Related Methods PLS, Paris, France 2014: The Multiple Facets of Partial Least Squares and Related Methods, pp. 285-293.

Kessous, A. 2015, "Nostalgia and brands: a sweet rather than a bitter cultural evocation of the past", Journal of Marketing Management, vol. 31, no. 17-18, pp. 1899-1923.

Kessous, A., Roux, E. \& Chandon, J.-L. 2015, "Consumer-Brand Relationships: A Contrast of Nostalgic and Non-Nostalgic Brands", Psychology \& Marketing, vol. 32, no. 2, pp. 187-202.

Koetz, C. \& Tankersley, J.D. 2016, “Nostalgia in online brand communities”, Journal of Business Strategy, vol. 37, no. 3, pp. 22-29.

Kral, P. 2012, Nostalgic Branding in Central Europe. In: Diversity in European Marketing: Text and Cases, Rudolph, T., Schlegelmilch, B.B., Franch, J., Bauer, A. \& Meise, J.N. (Eds), Springer Gabler, pp. 113-130.

Kusumi, T., Matsuda, K. \& Sugimori, E. 2010, "The effects of aging on nostalgia in consumers' advertisement processing", Japanese Psychologic Research, vol. 52, no. 3, pp. 150-162.

Lasaleta, J.D., Sedikides, C. \& Vohs, K.D. 2014, “Nostalgia weakens the desire for money”, Journal of Consumer Research, vol. 41, no. 3, pp. 713-729.

LaTour, K., LaTour, M.S. \& Zinkhan, G.M. 2010, "Coke is It: How stories in childhood memories illuminate an icon", Journal of Business Research, vol. 63, no. 3, pp. 328-336.

Lemmetti, H. \& Tuominen, P. 2017, Expatriates' Nostalgic Brand Relationships. Case Fazer Blue Chocolate in Regional Studies on Economic Growth, Financial Economics and Management, Proceedings of the 19th Euroasia Business and Economics Society Conference, Bilgin, M.H., Danis, H., Demir, E. \& Can, U. (Eds), pp. 401-422.

Levy, M., Weitz, B.A. \& Grewal, D. 2014, Retailing Management, 9th Edition, New York: McGraw-Hill Education.

Loveland, K.E., Smeesters, D. \& Mandel, N. 2010, "Still Preoccupied with 1995: The Need to Belong and Preference for Nostalgic Products", Journal of Consumer Research, vol. 37, no. 3, pp. 393-408.

Marchegiani, C. \& Phau, I. 2009, Effects of Personal Nostalgia on Cognition, Attitudes and Intentions, Marketing in Transition: Scarcity, Globalism, \& Sustainability, Proceedings of the 2009 World Marketing Congress, Campbell, C. L. (Ed), pp. $233-237$.

Marchegiani, C. \& Phau. I. 2010, “Away from "Unified Nostalgia”: Conceptual Differences of Personal and Historical Nostalgia Appeals in Advertising", Journal of Promotion Management, vol. 16, no. 1-2, pp. 80-95.

Marchegiani, C. \& Phau, I. 2012, "The effect of music on consumers' nostalgic responses towards advertisements under personal, historical and non-nostalgic conditions", The International Review of Retail, Distribution and Consumer Research, vol. 22, no. 1, pp. $27-53$.

Merchant, A., Latour, K., Ford, J.B. \& Latour, M.S. 2013, "How Strong is the Pull of the Past? Measuring Personal Nostalgia Evoked by Advertising", Journal of Advertising Research, vol. 53, no. 2, pp. 150-165.

Muehling, D.D. \& Sprott, D.E. 2004, "The Power of Reflection: An Empirical Examination of Nostalgia Advertising Effects", Journal of Advertising, vol. 33, no. 3, pp. 25-35.

Muehling, D.D. \& Pascal, V.J. 2011, “An Empirical Investigation of the Differential Effects of Personal, Historical, and Non-Nostalgic Advertising on Consumer Responses", Journal of Advertising, vol. 40, no. 2, pp. 107-122. 
Muehling, D.D. \& Pascal, V.J. 2012, "An Involvement Explanation for Nostalgia Advertising Effects", Journal of Promotion Management, vol. 18, no. 1 , pp. 110-118.

Muehling, D.D. 2013, "The relative influence of advertising-evoked personal and historical nostalgic thoughts on consumers' brand attitudes", Journal of Marketing Communications, vol. 19, no. 2, pp. 98-113.

Muehling, D.D., Sprott, D.E. \& Sultan, A.J. 2014, "Exploring the Boundaries of Nostalgic Advertising Effects: A Consideration of Childhood Brand Exposure and Attachment on Consumers' Responses to Nostalgia-Themed Advertisements", Journal of Advertising, vol. 43, no. 1, pp. 73-84.

Natterer, K. 2015, Nostalgia as the Future for Branding Entertainment Media? The Consumption of Personal and Historical Nostalgic Films and Its Effects. In: Handbook of Media Branding, Siegert, G., Förster, K., Chan-Olmsted, S.M. \& Ots, M. (Eds), pp. 199-214.

O'Shaughnessy, J. 2015, Competitive Marketing (RLE Marketing): A Strategic Approach, London: Routledge.

Orth, U.R. \& Bourrain, A. 2004, Consumer Behavioral Response to Scent-Evoked Nostalgia, Assessing the Different Roles of Marketing Theory and Practice in the Jaws of Economic Uncertainty, Proceedings of the 2004 Academy of Marketing Science (AMS) Annual Conference, Spotts, H.E. (Ed), pp. 231-235.

Orth, U.R. \& Gal, S. 2012, “Nostalgic brands as mood boosters", Journal of Brand Management, vol. 19, no. 8, pp. 666-679.

Orth, U.R. \& Gal, S. 2014, "Persuasive Mechanisms of Nostalgic Brand Packages", Applied Cognitive Psychology, vol. 28, no. 2, pp. 161-173.

Orth, U.R. \& Gal, S. 2015, Affect-Regulation Through Nostalgia-Shopping, Proceedings of the 2009 Academy of Marketing Science (AMS) Annual Conference, Robinson, L. (Ed), pp. 174.-174.

Pascal, V.J., Sprott, D.E. \& Muehling, D.D. 2002, “The Influence of Evoked Nostalgia on Consumers' Responses to Advertising: An Exploratory Study", Journal of Current Issues \& Research in Advertising, vol. 24, no. 1, pp. 39-47.

Percy, L. \& Elliott, R.H. 2016, Strategic Advertising Management, Oxford: Oxford University Press.

Ratnayake, N. \& Andrews, P. 2016, Power of Brands in Recalling Nostalgic Memories Among Young Adults: An Exploratory Study, in Let's Get Engaged! Crossing the Threshold of Marketing's Engagement Era, Proceedings of the 2014 Academy of Marketing Science (AMS) Annual Conference, Obal, M.W., Krey, N. \& Bushardt, C. (Eds), Springer, pp. 349-354.

Rindfleisch, A., Freeman, D. \& Burroughs, J.E. 2000, Nostalgia, Materialism, and Product Preference: an Initial Inquiry. In: NA - Advances in Consumer Research, vol. 27, Hoch, S.J. \& Meyer, R.J. (Eds), Provo, UT: Association for Consumer Research, pp. 36-41.

Routledge, C. 2015, Nostalgia: A Psychological Resource, New York: Psychology Press - Taylor \& Francis.

Ryynänen, T., Joutsela, M. \& Heinonen, V. 2016, "My Grandfather kept one of these tins on top of the bookshelf”: Consumers' recalled experiences involving packaging, Qualitative Market Research, vol. 19, no. 1, pp. 4-26.

Sedikides, C. \& Wildschut, T. 2016, "Past Forward: Nostalgia as a Motivational Force“, Trends in Cognitive Sciences, vol. 20, no. 5, pp. 319321.

Seger-Guttmann, T. \& Vilnai-Yavetz, I. 2015, Nostalgic Consumption: Does It Also Work for Services? Rediscovering the Essentiality of Marketing, Proceedings of the 2015 Academy of Marketing Science (AMS) World Marketing Congress, Petruzzellis, L. \& Winer, R.S. (Eds), pp. 881-886.

Shields, A.B. \& Johnson, J.W. 2016a, "Childhood brand nostalgia: A new conceptualization and scale development", Journal of Consumer Behaviour, vol. 15, no. 4, pp. 359-369.

Shields, A.B. \& Johnson, J.W. 2016b, "What Did You Do to My Brand? The Moderating Effect of Brand Nostalgia on Consumer Responses to Changes in a Brand", Psychology \& Marketing, vol. 33, no. 9, pp. 713-728.

Shin, H. \& Parker, J. 2017, "Exploring the elements of consumer nostalgia in retailing: Evidence from a content analysis of retailer collages", Journal of Retailing and Consumer Services, vol. 35, pp. 1-11.

Solomon, M.R., Bamossy, G., Askegaard, S. \& Hogg, M.K. (Eds) 2006, Consumer Behaviour: A European Perspective, 6th edition, Harlow: Prentice Hall.

Srivastava, E., Maheswarappa, S.S. \& Sivakumaran, B. 2017, "Nostalgic advertising in India: a content analysis of Indian TV advertisements", Asia Pacific Journal of Marketing and Logistics, vol. 29, no. 1, pp. 47-69.

Stern, B.B. 1992, "Historical and Personal Nostalgia in Advertising Text: The Fin de siècle Effect", Journal of Advertising, vol. 21, no. 4, pp. 11-22.

Sultan, A.J., Muehling, D. \& Sprott, D.E. 2010, The effect of personal attachment and usage on consumers' response to nostalgia, The Academy of Marketing Studies Proceedings, vol. 15, no. 2, Allied Academies International Conference, Las Vegas, October 13-16, 2010, pp. 1-3.

Vignolles, A. \& Pichon, P.-E. 2014, “A taste of nostalgia: Links between nostalgia and food consumption”, Qualitative Market Research: An International Journal, vol. 17 , no. 3, pp. 225-238. 
Wang, J. 2013, Communicating Nation Brands. In: Shaping China's Global Imagination: Branding Nations at the World Expo, New York: Palgrave Macmillan, pp. 87-108.

Zhao, G., Li, W., Teng, L. \& Lu, T. 2014, "Moderating Role of Consumer Self-Concept on the Effectiveness of Two Nostalgia Appeals", Journal of Promotion Management, vol. 20, no. 1, pp. 1-19.

Zhao, G., Muehling, D.D. \& Kareklas, I. 2014, "Remembering the Good Old Days: The Moderating Role of Consumer Affective State on the Effectiveness of Nostalgic Advertising", Journal of Advertising, vol. 43, no. 3, pp. 244-255.

Zhou, L., Wang, T., Zhang, Q. \& Mou, Y. 2013, "Consumer insecurity and preference for nostalgic products: Evidence from China”, Journal of Business Research, vol. 66, no. 12, pp. 2406-2411. 